\title{
TEACHING EMPLOYEES MONEY MANAGEMENT SKILLS AND SHOWING A PROFIT IN THE PROCESS: LESSONS FROM A FINANCIAL LITERACY COURSE
}

\section{Arnel Huisamen, Mike Weyers}

\section{INTRODUCTION}

Although deficient financial management skills have often been perceived as an "affliction of the poor", resent studies have shown it to be a problem that pervades all levels of South African society (Engelbrecht, 2008:3-15; FinMark Trust, 2009). There is also strong evidence that the financial problems that stem from mismanagement are one of the causal factors of the high levels of pilfering, bribery, corruption and theft in the country's public and private sectors (ACRC, 2009). In spite of this, very little is being done to address this deficiency. There is especially a dire need that employers should empower their workforce with appropriate financial management skills. One employer that has taken up this challenge is the South African Police Service (SAPS).

In 2003 the National Commissioner of the SAPS gave instructions that all new student constables should undergo a personnel capacity-building training programme as part of their basic training. This led to the development of the Self-Management Programme by Police Social Work Services. A financial management module entitled "Be Money Wise" formed a constituent part of this programme. The programme and module were first implemented in July 2004 and have since been presented to between 8000 and 11000 recruits annually.

In 2005 a comprehensive study by, amongst others, Huisamen (2005) was undertaken into the short- and long-term effects and return on investment (ROI) of the programme. This paper will, however, only focus on the nature of, and results achieved with, the "Be Money Wise" module. These data could then be used as a basis to develop similar programmes in other occupational settings and in generic social work practice.

In order to put the research results into perspective, it is first necessary to provide a brief overview of the nature of, and need for, financial literacy education.

\section{THE NEED FOR, AND BASIC NATURE OF, FINANCIAL LITERACY EDUCATION: A BRIEF OVERVIEW}

Deficiencies and the need for improvements in the financial literacy of citizens is a worldwide phenomenon. Various studies in first world, developed countries such as United States, United Kingdom, New Zealand and Australia have concluded that approximately half their populations exhibit serious deficiencies in their understanding of everyday financial matters (Fogarty \& MacCarthy, 2006:115; Skinner, 2007). South African citizens faired even worse. In a 2008 study, for example, only $43 \%$ of the adult respondents knew what the concept "bad debt" meant (FinMark Trust, 2009). Their grasp of other basic concepts was $25 \%$ for "counselling about debt", $22 \%$ for a "garnishee or emolument order", $21 \%$ for "debt administration" and $16 \%$ for "debt re-scheduling” (FinMark Trust, 2009).

Financial literacy is, however, not only a question of knowledge. Of even greater importance are attitudes towards and behaviour concerning financial issues (Huisamen \& Weyers, 2005:56, 75). The attitudinal and behavioural symptoms of poor financial literacy include: the overuse of credit cards to the point where debts cannot be met; using personal loans (including micro- 
credit) for consumption or to cover funeral costs; undertaking overly-optimistic car, clothing and home-loan obligations; and foolish commitments to get-rich-quick schemes (Beal \& Delpachitra, 2003:65-78; Oni, Obi, Okone, Thabede \& Jordaan, 2002). The consequences of such behaviours are potentially devastating from a societal, work and an individual point of view. They include, amongst various others: bankruptcies; marriage breakdowns where financial problems are often a common cause; personal hardship from growing debt and pressures to commit financial crimes (accepting bribes, corruption and theft) to stave off bankruptcy or maintain a standard of living to which the person has grown accustomed (Fogarty \& MacCarthy, 2006:115-116).

One of the causal factors of financial difficulties is a lack of financial literacy. It can, in this context, be defined as the ability to make effective decisions regarding the use and management of money and other assets (Fogarty \& MacCarthy, 2006:115). The primary purpose of financial literacy education would, therefore, be to prevent or rectify faulty financial decisions by increasing people's knowledge and understanding of key financial concepts and their implications, instilling in them the appropriate attitudes towards money and other financial assets and, especially, empower them with the skills, confidence and motivation required for effective financial management behaviour (Willis, 2008:1). Although the basis of these knowledge, attitudinal and behavioural requirements could and should be laid in the home and school environment, the work setting provides an ideal opportunity to take them a step further. The reason is that it is in this environment that the employee earns his or her income and is often most receptive to being influenced on spending it.

It should be noted that South African social workers and social auxiliary workers are not authorised financial service providers in terms of the Financial Advisory and Intermediary Services Act (No. 37 of 2002) or other legislation and, therefore, not allowed to give advice on specific financial choices (e.g. with whom to invest or which insurance package to choose). These issues should be referred to authorised providers. They can and must, however, make people aware of dangerous or "unsavoury" financial practices and change their attitudes towards money in order to prevent the social problems that stem from money mismanagement.

\section{THE CONTEXT AND NATURE OF THE SAPS “BE MONEY WISE” MODULE}

The "Be Money Wise" module of the South African Police Service forms part of a comprehensive Self-Management Programme that is presented over a five-day period during the basic training of all new recruits. The programme can be described as a structured personnel capacity-building intervention and is similar to the types of interventions that are sometimes referred to in literature as human resource development, personal effectiveness or life-skills training, psychosocial education, or personal and social education programmes (Kruger, 2001:20; Nelson-Jones, 1991:23; Rooth, 2000:34). It consists of eight modules (Diagram 1) and aims to enhance the recruits' resilience and ability to manage their professional and personal life more effectively. 
DIAGRAM 1:

COMPOSITION OF THE SELF-MANAGEMENT PROGRAMME

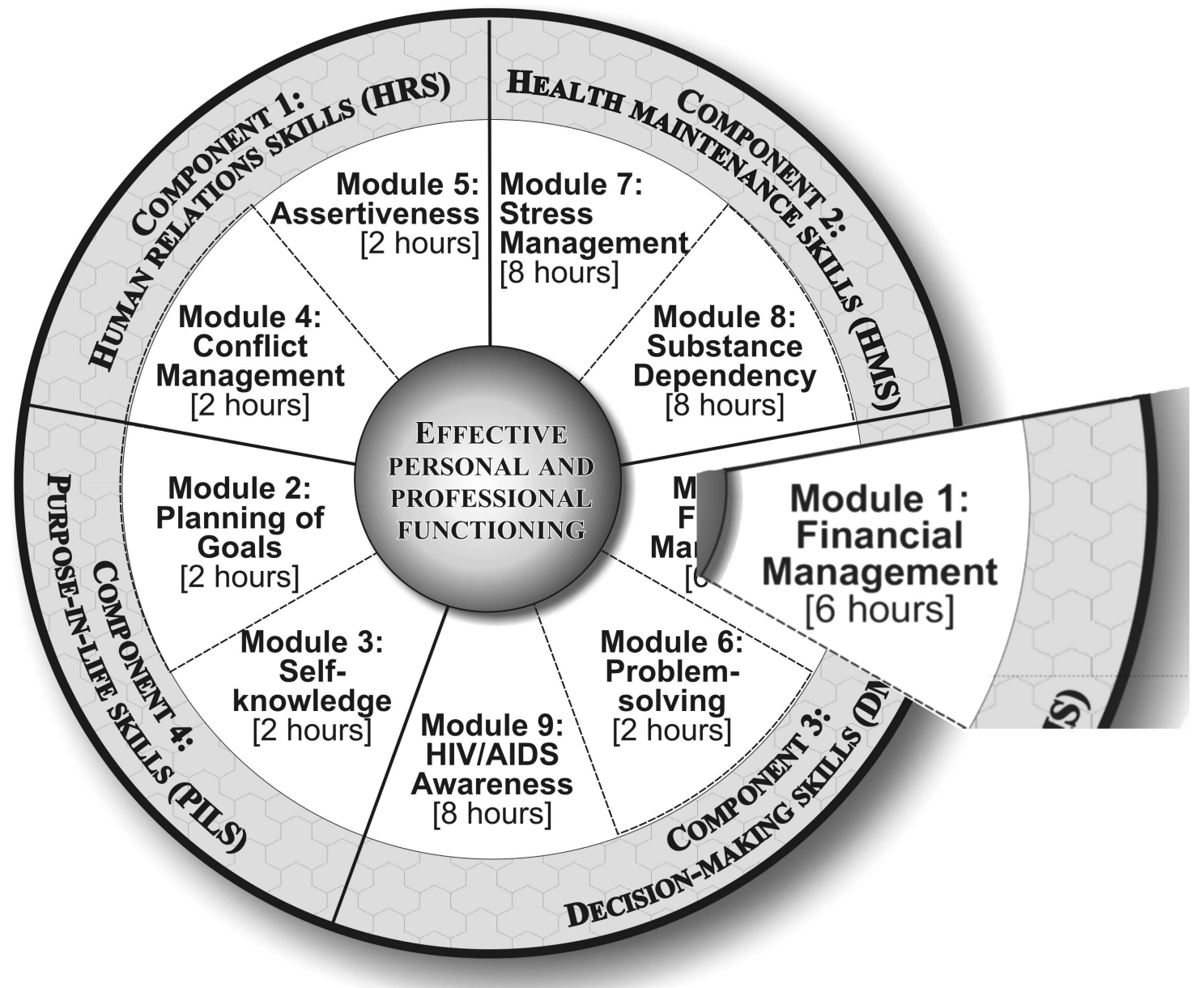

The six contact-hour long "Be Money Wise" module is presented on the first day of the SelfManagement Programme. Its intended outcome is to enable learners to "utilize their acquired knowledge and skills to secure their financial freedom" (SAPS, 2004a). In order to reach this goal, they should be able to:

- identify their attitudes towards money;

- utilise acquired knowledge on budgeting;

- identify ways to eliminate financial difficulties;

- ensure effective planning for future financial freedom;

- identify the effect that insufficient financial management has on their psycho-social functioning;

- identify the true cost of debt;

- utilise acquired knowledge to develop a mindset that would lead to success.

The modules are presented in a workshop format that makes extensive use of experiential learning methods. One social worker (presenter) is assigned to each platoon of between 28 to 36 recruits and is responsible for presenting the complete programme. During a workshop session a platoon is sometimes divided into four or five smaller groups in order to ensure optimal participation in discussions and experiential learning activities. 
The content, themes and procedures followed in the "Be Money Wise" module are summarised in Table 1.

TABLE 1

THE THEMES AND PRESENTATION OF THE “BE MONEY WISE” MODULE*

\begin{tabular}{|c|c|}
\hline Themes & Procedures and methods \\
\hline 1. Introduction & $\begin{array}{l}\text { - Presentation: The nature of money and financial } \\
\text { management }\end{array}$ \\
\hline 2. Attitudes towards money & $\begin{array}{l}\text { - "Attitudes towards money" (exercise in workbook) } \\
\text { - Small groups discussion } \\
\text { - Feedback from the small groups } \\
\text { - Large group discussion of theme }\end{array}$ \\
\hline $\begin{array}{l}\text { 3. How to have money in your } \\
\text { pocket the day before payday } \\
\text { Current financial status } \\
\text { Clustered expenses } \\
\text { Who need to draw up a budget? } \\
\text { How to budget }\end{array}$ & $\begin{array}{l}\text { - Presentation: Overview of personal financial situation } \\
\text { (exercise in workbook) } \\
\text { - Presentation: List of expenses (exercise in workbook) } \\
\text { - Presentation: A budget (transparency) } \\
\text { - Presentation: Salary advice (example in workbook) } \\
\text { - Completion of monthly budget (exercise in workbook) }\end{array}$ \\
\hline $\begin{array}{l}\text { 4. Financial difficulties } \\
\text { Debt management } \\
\text { Debt elimination } \\
\text { Basic principles of saving money } \\
\text { Resources }\end{array}$ & $\begin{array}{l}\text { - Presentation: Debt management } \\
\text { - Role play } 1 \text { and 2: Practise negotiation with debtor } \\
\text { (scenarios in workbook) } \\
\text { - Presentation: Debt elimination plan (example in workbook) } \\
\text { - Group exercise: Practical tips for saving (summary in } \\
\text { workbook) } \\
\text { - Group discussion: Resources listing (flipchart listing) }\end{array}$ \\
\hline $\begin{array}{l}\text { 5. Future financial freedom } \\
\text { Wills } \\
\text { Policies } \\
\text { Investments } \\
\text { Savings }\end{array}$ & $\begin{array}{l}\text { - Presentation: Financial freedom } \\
\text { - Presentation: "Prevention is better than cure" } \\
\text { (transparency) } \\
\text { - Group discussion: "Prevention is better than cure" } \\
\text { (flipchart listing) } \\
\text { - Presentation: "SAVE, SAVE, SAVE" (transparency) }\end{array}$ \\
\hline $\begin{array}{l}\text { 6. Consequences of not planning } \\
\text { Legal and financial consequences } \\
\text { Psycho-social consequences }\end{array}$ & $\begin{array}{l}\text { - Brainstorm by group: Consequences of not planning } \\
\text { (flipchart listing) } \\
\text { - Feedback by presenter: Highlights of consequences }\end{array}$ \\
\hline $\begin{array}{l}\text { 7. Financial fundamentals } \\
\text { True cost of debt }\end{array}$ & $\begin{array}{l}\text { - Presenter discussion: True cost of debt } \\
\text { - Presentation: "Household items" (transparency) } \\
\text { - Presentation: "Owning a car" (transparency) } \\
\text { - Presentation: "Buying a house" (transparency) } \\
\text { - Discussion }\end{array}$ \\
\hline $\begin{array}{l}\text { 8. Developing a success mindset } \\
\text { 8.1 How to open a bank account } \\
\text { 8.2 How to apply for a housing } \\
\text { subsidy } \\
\text { 8.3 How to apply for a state } \\
\text { guarantee } \\
\text { 8.4 How to apply for official housing } \\
\text { 8.5 All about contracts }\end{array}$ & $\begin{array}{l}\text { - Group discussion: The aspects of success } \\
\text { - Presentation: "Developing a success mind set" } \\
\text { (transparency) } \\
\text { - Presentation: Practical guidelines }\end{array}$ \\
\hline 9. Summary & - Presentation: Summary and conclusion \\
\hline
\end{tabular}

*(SAPS, 2004b) (Note: The module is copyrighted) 


\section{THE RESEARCH OBJECTIVES, DESIGN AND PROCEDURE}

In 2004 a decision was taken to subject the entire Self-Management Programme, including its "Be Money Wise" module, to a comprehensive effect measurement and return on investment (ROI) analysis. The purpose was not only to ascertain whether the intervention had a significant short- and long-term effect on recruits' knowledge, attitudes and behaviour, but also if it represented a worthwhile investment of the organisation's time, money and effort (Huisamen, 2005:4).

The research was undertaken by Huisamen and Weyers, and consisted of three main phases and accompanying research designs. These were the measurement of the module's short-term effect through the use of a quantitative experimental design, the ascertaining of its long-term effect with the help of more qualitative focus groups (Huisamen \& Weyers, 2005:50-95) and the use of a structured computerised schedule to measure its return on investment (ROI) coefficient (Weyers \& Huisamen, 2005:131-181).

In measuring the module's short-term effect, 400 experimental group and 120 control group participants were selected from the January 2005 intake of 4.249 recruits (i.e. a $9.9 \%$ sample size) on a stratified random basis. The experimental group consisted of four platoons from the more southerly Oudtshoorn training institution, six platoons from the northerly Pretoria and Jakkalsdans institutions, and four platoons from Bisho in the eastern part of the country. The control group came from the other three SAPS training institutions at Philippi, Graaff-Reinet and Chatsworth (the programme was presented to them a week after that of the experimental group).

Two categories of measuring instruments, viz. the knowledge, attitudes and behaviour (KAB) questionnaires and a presentation evaluation questionnaire, were utilised in the measuring of effect.

- The KAB questionnaires were aimed at measuring the programme's impact on the participants' knowledge, attitude and behaviour (i.e. KAB) and were completed before and after the presentation of the module. A programme value scale was included in the post-test, enabling the experimental group to evaluate the value of each module.

- The standardised Facilitation Assessment Scale (Weyers \& Rankin, 2007:6) was used to measure the participants' experience of the presenters' presentations and the relevance of the module.

- In order to enhance the validity of interpretations, all the data/measurements were triangulated (Bryman, 2003; Hilton, 2002; Patton, 2002; Weyers, Strydom \& Huisamen, 2008:210).

In addition to the experimental and control groups, focus groups consisting of a total of 113 recruits were utilised to ascertain the long-term effect of the modules. Availability sampling was used to select the participants from police stations in the more northerly Gauteng province and the Southern Cape during July/August 2005. All the participants had completed the SelfManagement Programme during January 2005, but were not necessarily respondents in the main empirical study.

After the results of the effect measurements became known, a start was made with the measurement of the ROI. An adapted form of a very extensive computerised measurement framework and formulas that were developed by Meyer, Opperman and Dyrbye (2003) was 
used for this purpose. It covered three broad issues, namely the costs involved in the service, the benefits derived from it and the results that were achieved.

\section{THE SHORT-TERM EFFECT OF THE MODULE}

Each scale's Cronbach alpha coefficient was calculated in order to determine its reliability (Gravetter \& Forzano, 2003:455). Because of the nature of the study, a score of 0.5 or higher was accepted as an appropriate reliability coefficient (Jackson, 2003:87-91). In order to measure whether the intervention brought about practical significant change, use was made of Cohen's formula for the calculation of effect size (i.e. "d-value") (Cohen, 1988:20-27; Steyn, 2000:1-3). The resultant $\alpha$ - and d-values are summarised in Table 2.

TABLE 2

THE EFFECT OF THE “BE MONEY WISE” MODULE"

\begin{tabular}{|l|c|c|c|}
\hline \multicolumn{1}{|c|}{ Scales } & CA $(\boldsymbol{\alpha})$ & $\mathbf{n}$ & d-values \\
\hline Scale 1: Objective knowledge (Individual questions:) & 0.47 & & \\
\hline $\begin{array}{l}\text { - People whose debt exceeds their ability to pay can be placed } \\
\text { under debt administration }\end{array}$ & & 530 & $0.57^{*}$ \\
\hline $\begin{array}{l}\text { - People who are placed under debt administration may still } \\
\text { buy items on credit }\end{array}$ & 533 & $0.62^{*}$ \\
\hline $\begin{array}{l}\text { - If a person is blacklisted for bad debt, that blacklisting will } \\
\text { last for one year }\end{array}$ & 531 & $0.61^{*}$ \\
\hline - Money for your car's maintenance is a fixed expense & & 530 & $0.64^{*}$ \\
\hline - Buying a Lotto ticket is a variable expense & & 528 & $0.59^{*}$ \\
\hline Scale 2: Subjective knowledge & $0.91^{\square}$ & 533 & $2.58^{* *}$ \\
\hline Scale 3: Attitude & $0.52^{\square}$ & 533 & $0.97^{* *}$ \\
\hline Scale 4: (Intended) Behaviour & $0.84^{\mathbf{\Xi}}$ & 516 & $2.76^{* *}$ \\
\hline
\end{tabular}

${ }^{\square}$ Reliable scales $*$ Medium effect: $d \leq 0.5 * *$ Practical significant effect: $d \leq 0.8 *$ (Huisamen \& Weyers, 2005:74)

\section{The effect on objective knowledge (Scale 1)}

Scale 1 was intended to measure changes (i.e. increase/decrease) in the respondents' factual knowledge. As a whole, the scale turned out to be somewhat unreliable (probably because of deficiencies in the questions) and could not be used as such $(\boldsymbol{\alpha}=0.47)$. A covariance analysis of individual items did, however, indicate that the module had a medium effect on their factual knowledge of some issues.

\section{The effect on subjective knowledge (Scale 2)}

The second scale dealt with the extent to which respondents felt that their knowledge had increased (or not). This produced a very high and practical significant d-value of 2.8. This implied that, even though it could not be proven beyond doubt that there was an actual increase in knowledge, the participants at least felt that this was the case.

\section{The effect on attitudes (Scale 3)}

The module had a practical significant effect $(\mathrm{d}=0.97)$ on the respondent's attitudes to financial management issues. 


\section{The effect on behaviour (Scale 4)}

The biggest and most important short-term effect of the "Be Money Wise" module was on the respondents intended behaviour $(\mathrm{d}=2.76)$. The question then arose to what extent these intentions would translate into actual, internalised behaviour patterns. The answers were sought during focus group discussions that were held six to seven months after the initial training sessions.

\section{THE LONG-TERM EFFECT OF THE MODULE}

Focus group interviews brought the following trends to the fore:

\section{Budgets}

After six months the majority of the focus group members still completed and tried to keep to a budget every month. According to them, this represented a complete change from their behaviour prior to the training.

\section{Avoiding poor financial behaviour}

Most of them were able to identify ineffective financial behaviour, such as buying on credit, micro loans and living extravagantly. They also reported that they were now able to avoid these pitfalls.

\section{Positive financial behaviour}

The group members reported that the programme had changed their knowledge of, and attitudes towards, saving, investments and life insurance policies. They realize that they have to make provision for retirement and financial freedom. Most had already taken active steps in this regard.

\section{Impact of the module}

There were indications that the respondents had forgotten some of the more technical knowledge that they had originally gained through the module (e.g. the nature of garnishee orders). However, this did not prevent a lasting change in behaviour.

\section{THE MODULE'S RETURN ON INVESTMENT (ROI)}

Return on investment (ROI) analyses can be defined as the scientific measurement of the monetary benefits obtained by an organisation over a specified period in return for a given investment in a service delivery programme (Meyer et al., 2003:5). These types of studies in the social and behavioural sciences are still in their infancy, mainly because of a general lack of scientific data on the incidence rates of behaviour patterns and social problems in society. Researchers in this emerging field consequently have to rely heavily on indicators in their calculations. The same hurdle had to be overcome in the calculation of the "Be Money Wise" module's ROI.

Two categories of benefits were used in the calculation of the module's ROI, viz. improvements in the quality of services/productivity (Table 3: Section A), and labour and other cost savings (Table 3: Section B). The results of the measurement of these benefits are contained in Table 3. 
TABLE 3

THE BENEFITS OF THE “BE MONEY WISE”' MODULE *

\begin{tabular}{|c|c|c|c|}
\hline \multicolumn{4}{|c|}{ CALCUlation OF BENEFITS } \\
\hline $\begin{array}{l}\text { SECTION A: } \\
\text { IMPROVEMENTS IN QUALITY OF SERVICE }\end{array}$ & $\begin{array}{l}\text { Variable 1: } \\
\text { Estimated \% of } \\
\text { recruits that will } \\
\text { be affected }\end{array}$ & $\begin{array}{c}\text { Variable 2: } \\
\text { Average \% } \\
\text { net value that } \\
\text { will be } \\
\text { utilised }\end{array}$ & $\begin{array}{l}\text { Potential } \\
\text { improvements } \\
\text { per year per } \\
\text { recruit }\end{array}$ \\
\hline $\begin{array}{l}\text { Total number of recruits: } 8538 \text { (2005); } \\
11000(2006) \& 11000(2007)\end{array}$ & $25.0 \%$ & $7.24 \%$ & R2 153 \\
\hline Total & & & R2 153 \\
\hline $\begin{array}{l}\text { Variable 3: Estimated extent to which value } \\
\text { will translate into actual improvements in } \\
\text { quality of service }\end{array}$ & $6.9 \%$ & & \\
\hline \multirow{2}{*}{$\begin{array}{l}\text { Total yearly financial value of the improved } \\
\text { quality of service }\end{array}$} & Year $1(2005)$ & Year $2(2006)$ & Year $3(2007)$ \\
\hline & R1 264533 & R1 629171 & R1 629171 \\
\hline \multicolumn{4}{|l|}{$\begin{array}{l}\text { SECTION B: } \\
\text { LABOUR AND OTHER COST SAVINGS PER } \\
\text { YEAR }\end{array}$} \\
\hline $\begin{array}{l}\text { Variable 4: Rand equivalent of expected } \\
\text { reduction in production loss due to financial } \\
\text { problems related to personal telephone calls }\end{array}$ & R4 764204 & R5 240624 & R5 764687 \\
\hline $\begin{array}{l}\text { Variable 5: Rand equivalent of expected } \\
\text { reduction in production loss due to financial } \\
\text { problems related to conversations with } \\
\text { colleagues }\end{array}$ & R3 811363 & R4 192499 & R4 611749 \\
\hline $\begin{array}{l}\text { Variable 6: Rand equivalent of expected } \\
\text { reduction in production loss due to financial } \\
\text { problems induced absenteeism }\end{array}$ & R1 009112 & R1 110023 & R1 221026 \\
\hline \multicolumn{4}{|l|}{$\begin{array}{l}\text { Variable 7: Calculation of the net } \\
\text { contribution of the module }\end{array}$} \\
\hline $\begin{array}{l}\text { Average \% net improvement in knowledge, } \\
\text { attitudes and behaviour }(K A B)\end{array}$ & $22.94 \%$ & $22.94 \%$ & $22.94 \%$ \\
\hline $\begin{array}{l}\text { Estimated percentage }(\%) \text { contribution } \\
\text { that } K A B \text { will make to labour and cost } \\
\text { savings }\end{array}$ & $10 \%$ & $10 \%$ & $10 \%$ \\
\hline \multirow{2}{*}{ Total labour and other cost savings per year } & Year 1 (2005) & Year $2(2006)$ & Year $3(2007)$ \\
\hline & R958 468 & R1 054315 & R1 159746 \\
\hline $\begin{array}{l}\text { Total value of the module } \\
(\text { Section } A+\text { Section } B)\end{array}$ & R2 223001 & R2 312657 & R2 78817 \\
\hline
\end{tabular}

*(Weyers \& Huisamen, 2005:151)

The variables as summarised in Table 3 will next be described in more detail. 


\section{Section A: Improvements in quality of service}

\section{Variable 1: Estimated percentage of recruits that will be affected}

In the calculation of the module's benefits, it was firstly assumed that at least $25 \%$ of all recruits would, in the normal course of events, be negatively affected by some or other form of financial problems. This assumption is based in part on the following research findings:

- Between $15 \%$ and $20 \%$ of workers in the USA experience such financial problems and associated stress that it impacts negatively on their productivity (Joo, 1998:3; Kim \& Garman, 2004:69);

- Financial stress causes $30 \%$ of the personal and work dissatisfaction experienced by employees (Bailey, Woodiel, Turner \& Young, 1998:198);

- In a study done in South Africa 53\% of the respondents maintained that financial problems affect their productivity (Masemola, 2003: Chart 9). In the case of one employer, the proportion of workers that experienced such financial problems that they negatively impacted on their productivity ranged between $40 \%$ and 50\% (Masemola, 2003).

If both the South African (40\%-50\%) and international (15\%-20\%) research findings are taken as a basis and applied to the profile of SAPS recruits (low income and mostly young, first time employed), it is conservatively estimated that at least $25 \%$ would experience serious financial problems. This estimate was to some extent substantiated by the findings of the focus group discussions.

\section{Variable 2: Average percentage net value ascribed to the intervention}

The study into the effect of the "Be Money Wise" module contained a scale that dealt exclusively with the contribution that the module could make to the improvement in the recruits' quality of service. The result of this "value of the module" scale measurement could, therefore, be used in Variable 2: "Average \% net value ascribed to the intervention". The formula entailed the following:

- $($ Middle of scale - Mean $) \div$ Middle of scale $=$ Net $\%$ above average

The net $\%$ above average value came to $72.36 \%$. It was further discounted by a factor of 10 . This would imply that of the $25 \%$ recruits who will experience serious financial problems and viewed the module as of great value, only one in 10 would actually and actively use it in their lives.

\section{Variable 3: Estimated percentage contribution to improvement of quality of services}

Variable 3 was included in the calculation of a module's monetary benefits because not all the value derived from the intervention would necessarily translate directly into service quality improvements. It also had to be relevant to the specific work environment and the recruits would have to apply the knowledge, attitudes and skills they have gained in their personal and work lives.

In the calculations the result of the application of the Relevance scale was used as a baseline. Its net $\%$ above average came to $68.8 \%$. This figure was also discounted by a factor of 10 . It would, therefore, imply that of the $25 \%$ of recruits who will experience serious financial problems and the $7.236 \%$ of these who will use its potential value, only one in 10 would be able to convert this potential value into an actual improved quality of service.

The results of the very conservative application of variables 1 to 3 indicate that the monetary value of improvements to the quality of services would come to: 
- R1 264533 for 2005;

- R1 629171 for 2006;

- R1 629171 for 2007 (Table 3).

\section{Section B: Labour and other cost savings}

Only three primary variables or indicators were used to calculate the potential labour and other cost savings that the module would bring about. They were the production loss as a result of financial problems related to (1) telephone calls and (2) conversations with colleagues during work-hours, as well as (3) the expected cost of financial stress-related absenteeism.

These three variables had to be chosen not because they necessarily represented the biggest financial cost item to employers because of employees' mismanagement of their personal financial affairs, but because their impact has been fairly well researched (Garman, 1997; Kim \& Garman, 2004:70; Masemola, 2003). It was also assumed that if changes to these behaviour patterns would substantially benefit employers, the overall value of a financial literacy education programme would be even greater.

Some factors that have a negative effect on productivity but that had to be excluded because of a lack of scientific impact measurements included the following (Alper, 2002; Joo, 1998:245; Kim \& Garman, 2004:70; Lee, 1997; Masemola, 2003).

- Involvement in corrupt activities: Employees who have financial problems have a predisposition to become involved in the soliciting of bribes, theft, the leaking of classified/secret information and blackmail in order to supplement their income.

- Problems related to credit: Credit allows people to buy more than they basically need and often results in huge financial problems. In the study by Masemola (2003), 47\% of the respondents indicated that they sometimes reach the maximum limit on their credit. Such overspending can result in:

- regularly borrowing money from colleagues or friends;

- regularly receiving communications from collection agencies;

- being sued for financial reasons;

- being evicted from rental housing or having one's home foreclosed;

- having tax refund intercepted by a government agency or court order;

- having wages garnished;

- considering personal bankruptcy;

- being imprisoned for debt.

- Problems related to gambling: Employees who have financial problems are more prone to losing money to rip-offs and frauds, on buying lottery tickets and on gambling. It can result in desperation gambling in order to avoid the consequences of problems caused by earlier gambling, asking (begging) for a major loan from family and friends to pay off major debts or embarking on dishonest practices.

- Financial problems and substance abuse: There are strong indications that the stress caused by financial problems can trigger alcohol and drug abuse in some employees. This, in turn, can cause a myriad of other problems such as on-the-job accidents. 


\section{Variable 4: Reduction in the work-time spent on the telephone on personal financial problems}

In order to arrive at an average of the time spent on telephone calls regarding financial matters, the results of studies by three different researchers were compared. Although they used different items in their measurement, all three used the average length of the conversations (not the number of calls) as a criterion. The resulting averages as a percentage of the total time spent on the phone are summarised in Table 4.

TABLE 4

AVERAGE TIME SPENT ON THE TELEPHONE ON PERSONAL FINANCIAL ISSUES

\begin{tabular}{|c|c|c|c|c|}
\hline \multirow[b]{2}{*}{ Item } & \multicolumn{3}{|c|}{ Authors } & \multirow[b]{2}{*}{ Average } \\
\hline & $\begin{array}{c}\text { Joo } \\
(1998: 142)\end{array}$ & $\begin{array}{c}\text { Kim \& Garman } \\
(2004: 72)\end{array}$ & $\begin{array}{c}\text { Masemola } \\
\text { (2003) }\end{array}$ & \\
\hline $\begin{array}{l}\text { Made/received calls regarding } \\
\text { overdue credit payments }\end{array}$ & $12.6 \%$ & $6.2 \%$ & - & $9.4 \%$ \\
\hline $\begin{array}{l}\text { - } \begin{array}{l}\text { Made calls to friends and/or } \\
\text { relatives about financial matters }\end{array} \\
\end{array}$ & $12.2 \%$ & $7.5 \%$ & - & $9.85 \%$ \\
\hline - Made calls to a lawyer & $11.5 \%$ & - & - & $11.5 \%$ \\
\hline $\begin{array}{l}\text { - Made calls to a credit/budget } \\
\text { counsellor }\end{array}$ & $3 \%$ & $1.2 \%$ & - & $2.1 \%$ \\
\hline $\begin{array}{l}\text { Made calls to arrange a vehicle } \\
\text { loan }\end{array}$ & $8.9 \%$ & - & - & $8.9 \%$ \\
\hline $\begin{array}{l}\text { - Spent time on the phone regarding } \\
\text { financial matters }\end{array}$ & - & - & $13 \%$ & $13 \%$ \\
\hline TOTAL & $60.8 \%$ & $14.9 \%$ & $13 \%$ & $29.6 \%$ \\
\hline
\end{tabular}

TABLE 5

VARIABLE 4: EXPECTED PRODUCTION LOSS DUE TO TIME SPENT ON THE TELEPHONE ON PERSONAL FINANCIAL ISSUES

\begin{tabular}{|l|l|c|}
\hline \multicolumn{1}{|c|}{ Item } & \multicolumn{1}{c|}{ Calculation } & \multicolumn{1}{c|}{ Result } \\
\hline - $\begin{array}{l}\text { Expected total number of recruits that would } \\
\text { experience financial problems/stress per annum: }\end{array}$ & $25 \%$ x 8538 recruits $=$ & $\begin{array}{l}2134.5 \\
\text { recruits }\end{array}$ \\
\hline $\begin{array}{l}\text { - Estimated hours that one recruit will spend on the } \\
\text { telephone per annum: }\end{array}$ & $\begin{array}{l}12.5 \% \text { x 1920 hours } \\
\text { (total working hours in } \\
\text { a year) }=\end{array}$ & 240 hours \\
\hline $\begin{array}{l}\text { - Estimated hours that one recruit spent on the } \\
\text { telephone on personal financial matters: }\end{array}$ & $15 \%$ x 240 hours $=$ & 36 hours \\
\hline - $\begin{array}{l}\text { Total hours spent on the telephone by affected } \\
\text { recruits on personal financial matters: }\end{array}$ & $\begin{array}{l}2134.5 \text { recruits x 36 } \\
\text { hours = }\end{array}$ & 76842 hours \\
\hline $\begin{array}{l}\text { - Estimated production lost because of financially } \\
\text { related personal calls during work-time: }\end{array}$ & $\begin{array}{l}76842 \text { hours x R62 } \\
\text { (average rate per hour) }\end{array}$ & $\mathbf{R 4 ~ 7 6 4 ~ 2 0 4}$ \\
\hline
\end{tabular}


In calculating of production loss as a result of personal financial telephone calls, the average hourly remuneration of a SAPS employer (SAPS, 2005:161) was taken as a basis. Because of the nature of the work that they will be doing in the organisation, it was estimated that recruits will spend $12.5 \%(1 / 8)$ of their average workday on the telephone. If the general circumstances of recruits are taken into consideration, it was also conservatively estimated that an average of $15 \%$ of this time would be spent on financial issues (Table 4). All three of the indicators were used in calculating the production loss as a result of hours spent on the telephone on personal financial issues (Table 5).

\section{Variable 5: Reduction in the time spent on talking to co-workers about financial issues}

Research done by Joo (1998:142, 249) and Kim and Garman (2004:72) found that employees spent, apart from telephone calls, considerable additional time on discussing money problems with co-workers. This ranged from 16.6\% (Kim \& Garman, 2004:72) to 44.8\% (Joo, 1998:142). In calculating the effect of this, it was estimated that recruits will spend 5\% (24 minutes) of their average workday on personal talks with co-workers and that, conservatively estimated, an average of $15 \%$ of this time will be spent on financial issues (Kim \& Garman, 2004:72). The production loss that will be brought about by this trend is contained in Table 6.

\section{TABLE 6}

\section{VARIABLE 5: EXPECTED PRODUCTION LOSS DUE TO TIME SPENT ON DISCUSSING FINANCIAL PROBLEMS WITH CO-WORKERS}

\begin{tabular}{|c|c|c|}
\hline Item & Calculation & Result \\
\hline $\begin{array}{l}\text { - Expected total number of recruits that would } \\
\text { experience financial problems/stress per annum: }\end{array}$ & $25 \% \times 8538$ recruits $=$ & $\begin{array}{l}2134.5 \\
\text { recruits }\end{array}$ \\
\hline $\begin{array}{l}\text { - Estimated hours that one recruit will spend on } \\
\text { non-work-related conversations with co-workers } \\
\text { per annum: }\end{array}$ & $\begin{array}{l}5 \% \text { x } 1920 \text { hours (total } \\
\text { working hours in a } \\
\text { year) }=\end{array}$ & 96 hours \\
\hline $\begin{array}{l}\text { - Estimated hours that one recruit spent on } \\
\text { conversations with co-workers regarding } \\
\text { financial problems per annum: }\end{array}$ & $15 \% \times 96$ hours $=$ & 14.4 hours \\
\hline $\begin{array}{l}\text { Total hours spent on the discussion of personal } \\
\text { financial matters: }\end{array}$ & $\begin{array}{l}2134.5 \text { recruits } \times 14.4 \\
\text { hours }=\end{array}$ & 30737 hours \\
\hline $\begin{array}{l}\text { - Estimated production lost due to financially } \\
\text { related personal discussions amongst employees: }\end{array}$ & $\begin{array}{l}30737 \text { x R62 (average } \\
\text { rate per hour) x } 2 \\
\text { (average number of } \\
\text { employees involved)* }\end{array}$ & R3 811363 \\
\hline
\end{tabular}

* Production loss will accrue from both the recruit and at least one co-worker he/she will talk to

\section{Variable 6: Reduction in absenteeism as a result of financial problems}

Financial problems can be viewed as a major cause of stress (Garman, 1997). This phenomenon has been substantiated by the research of, amongst others, Kim and Garman (2004:70) who found that $21 \%$ of their respondents were highly "financially stressed". In turn, stress can lead to:

- physical disorders (50\%-80\% of such disorders have some stress component); 
- outpatient visits (70\%-90\% of such visits are stress related);

- frequent illnesses (workers with high stress levels are three times more likely to suffer from illnesses); and

- accidents (staff with high stress levels are 30\% more likely to have accidents than those with low stress) (Alper, 2002; Lee, 1997).

The study done by Kim and Garman (2004:70) found that respondents could be clustered into three groups, viz. those with low financial stress (43\%), moderate financial stress (36\%) and high financial stress (21\%). The latter group was absent from their work, on average, three days more than the others (Joo, 1998:140; Kim \& Garman, 2004:72). For the purposes of this study only one of these three extra days will be ascribed to financial problems. This assumption is somewhat vindicated by a South African study of Masemola (2003), who found that $13 \%$ of his respondents stayed away from work as a result of financial problems.

Absenteeism has enormous cost implications for any organisation. Apart from the work-hours lost by the individual, it results in higher overtime cost for replacement workers, more accidents, greater staff turnover, lessening of work efficiency, higher stress levels of other workers because of higher work-loads, increased health care costs and losses from lowered productivity (Joo, 1998:54). The extent to which recruits' absenteeism induced by financial problems could impact the SAPS is summarised in Table 7. In these calculations, only the one day extra taken off because of financial problems will be covered and not any of the other potential cost items.

\section{TABLE 7}

VARIABLE 6: EXPECTED PRODUCTION LOSS BECAUSE OF ABSENTEEISM INDUCED BY FINANCIAL PROBLEMS

\begin{tabular}{|c|l|l|}
\hline \multicolumn{1}{|c|}{ Item } & \multicolumn{1}{c|}{ Calculation } & \multicolumn{1}{c|}{ Result } \\
\hline \begin{tabular}{l} 
- $\begin{array}{l}\text { Expected total number of recruits that would } \\
\text { experience financial problems/stress per } \\
\text { annum: }\end{array}$ \\
\hline $\begin{array}{l}\text { - Total number of days lost by recruits due to } \\
\text { financial problems induced absenteeism: }\end{array}$
\end{tabular} & 2134.5 recruits x 1 day $=$ & 2134.5 days \\
\hline - Total cost of days lost due to absenteeism: & $\begin{array}{l}2134.5 \text { days x R496 recruits }= \\
\text { (average daily rate) }=\end{array}$ & $\mathbf{R 1 ~ 0 0 9 ~ 1 1 2}$ \\
\hline
\end{tabular}

\section{Variable 7: The net contribution of the module to labour and other cost savings}

In determining the modules' contribution to labour and other cost savings, the average net improvements that were brought about in the recruits' knowledge, attitudes and behaviour (KAB) were first calculated. This came to an average of $22.94 \%$. This total was then again discounted to a very conservative $10 \%$ for 2005 and each of the following two years. This implies that, of the expected total number of recruits that would experience financial problems/stress per annum, only 1 in 10 would actually change their behaviour to such an extent that it would bring about labour and other cost savings for the organisation. Based on all these calculations, the total labour and other cost savings per annum should come to:

- R958 468 for 2005; 
- R1 054315 for 2006;

- R1 159746 for 2007.

\section{The module's ROI and associated measurements}

The results of the calculation of the module's return on investment (ROI), net present value (NVP), payback period, internal rate of return (IRR) and learning cost per recruit are contained in Table 8.

TABLE 8

ROI AND ASSOCIATED MEASUREMENTS OF THE "BE MONEY WISE" MODULE

\begin{tabular}{|l|c|c|c|}
\hline & Year 1 (2005)* & Year 2 (2006)* & Year 3 (2007)* \\
\hline ROI (Return on Investment) & $4581 \%$ & $10166 \%$ & $16005 \%$ \\
\hline NPV (Net Present Value)* & R1 858243 & R4 173 985 & R6 595 160 \\
\hline Payback Period (months) & 0.26 & & \\
\hline IRR (Internal Rate of Return) & $4481 \%$ & $4600 \%$ & $4603 \%$ \\
\hline Learning cost per delegate & R36 & & \\
\hline
\end{tabular}

*(All costs/benefits calculated in terms of 2007 Rand value) * (Weyers \& Huisamen, 2005:157)

Each of the ROI, NVP, payback period, IRR and learning cost per recruit calculations has its own strengths and weaknesses. To provide a clear and complete picture of the return that the SAPS received on their investment in the module, the nature and results of each of these measurements will be discussed separately.

The ROI represents the percentage return on the intervention over the period of three years. It equals the present value of the accumulated net benefits (gross benefits less ongoing costs) over the three years divided by the initial costs. Three years are used as the time span because the modules might become obsolete after this time. The calculations entail the following:

- With the initial total cost of R41 466 the ROI would be 4581\% (year 1), 10166\% (year 2) and $16005 \%$ (year 3).

- This implies that for every R1 spent on this module, the return for the SAPS will be R4 581 (year 1), R10 166 (year 2) and R16 005 (year 3).

- SAPS will, theoretically, recoup its investments in the module within 0.26 months $(0.26 \mathrm{x}$ 22 work days $\approx 5.7$ workdays).

Internal rate of return (IRR) equals the percentage rate by which to discount the net benefits for the time period until the point that they equal the initial costs. For this module, the IRR or investment rate was equal to $4481 \%$ (2005), 4600\% (2006) and 4603\% (2007).

The last calculations that were done were the learning cost per recruit. This is calculated by dividing all the costs incurred in the development, presentation and evaluation of a module by the number of recruits to whom the programme will be presented over the three years. It came to R36 per recruit for the "Be Money Wise" module (Weyers \& Huisamen, 2005:151-157). 


\section{MAIN FINDINGS AND THEIR IMPLICATIONS}

The "Be Money Wise" module had a practical significant short-term effect on the recruits' financial management-related knowledge, attitudes and behaviour. The focus groups indicated that this result, especially as far as behavioural change is concerned, remained mostly unchanged for the next six to seven months. It could, therefore, be concluded that the module did not only change the way in which the student constables managed their finances in the short term, but that it would probably continue indefinitely. This would not only make a difference on a personal level, but would also make them less susceptible to bribery and other moneyrelated misbehaviour in the performance of their policing duties.

The structure, content and presentation plan of the "Be Money Wise" module as provided in this article could be used as either a blueprint or a guideline for the development of similar interventions in other settings. Any adaptations should, however, remain true to the original module's trifocal attention to the increasing of knowledge, the changing of attitudes and the embedding of new financial management behaviour in recipients. Only in this way could longterm change be assured.

With an ROI of $2594 \%$ during only the first year of presentation and a payback period of less than a month, it is obvious that the module represented an excellent investment of the SAPS's money, time and effort. In other occupational social work settings, this finding could be used as part of the motivation for implementing similar programmes. If undertaken successfully, it would also benefit the organisation in various other direct and indirect ways, including an increase in the general social wellbeing of its workforce and a reduction in the "embarrassment cost" and losses because of employees' financial crimes.

Even though the findings covered in this article were attained within an occupational setting, there is no reason why similar results could not also be achieved in generic social work practice. This would especially provide a response to the plea by authors such as Engelbrecht (2008:4-5,15) that financial literacy education should become an integral part of developmental social work and welfare in South Africa. The extensive implementation of money management programmes, similar to the "Be Money Wise" module, would also strike at one of the root causes of the financial difficulties that community members often experience: not a lack of money per se, but an inability to manage available money effectively. The ROI indicated that such services to the broad community would also represent a cost-effective investment of the social worker's professional time and effort.

\section{REFERENCES}

\section{ACRC see ANTI-CORRUPTION RESOURCE CENTRE.}

ALPER, S. 2002. Is stress nibbling away at your bottom line? Link \& Learn eNewsletter, November. Available: http://www.linkageinc.com/company/news_events/link_learn_enewsletter/archive/2002/ 11 02_stresspt1_alper.aspx [Accessed: 03/04/2005].

ANTI-CORRUPTION RESOURCE CENTRE. 2009. Causes \& consequences of corruption. Available: http://www.u4.no/ [Accessed: 26/02/2009].

BAILEY, W.C., WOODIEL, D.K., TURNER, M.J. \& YOUNG, J. 1998. The relationship of financial stress to overall stress and satisfaction. Personal Finances and Worker Productivity, 2(2):837-868.

BEAL, D.J. \& DELPACHITRA, S. 2003. Financial literacy among Australian university students. Economic Papers, 22(1):65-78. 
BRYMAN, A. 2003. Triangulation. Available: http://www.referenceworld.com/sage/social science/triangulation.pdf [Accessed: 13/09/2003].

COHEN, J. 1988. Statistical power analysis for the behavioral sciences $\left(2^{\text {nd }}\right.$ ed). Hillsdale (NJ): Erlbaum.

ENGELBRECHT, L. 2008. Financial literacy education within a developmental social work paradigm. Social Work/Maatskaplike Werk, 20(1):3-20.

FINMARK TRUST. 2006. More get bank accounts but SA financial divide persists. Available: http://www.finscope.co.za/documents/2009/PRFS08 education.pdf [Accessed: 24/02/2009].

FINMARK TRUST. 2009. SA needs more financial education (press release). Available: http://www.finscope.co.za/documents/2009/PRFS08_education.pdf [Accessed: 23/2/2009].

FOGARTY, G.J. \& MacCARTHY, K. 2006. Financial literacy: a psychologist's perspective on an emerging societal problem in Australia. Joint Conference of the Australian Psychological Society and the New Zealand Psychological Society, 26-30 Sept 2006, Auckland, New Zealand.

GARMAN, E.T. 1997. Conference to explore issues of financial stress and worker productivity. Available: http://www.sciencblog.com/community/older/1997/B/ 199701347. html [Accessed: 10/01/2005].

GRAVETTER, F.J. \& FORZANO, L.B. 2003. Research methods for the behavioral sciences. Belmont (Calif.): Thomson/Wadsworth.

HILTON, A. 2002. Should qualitative and quantitative studies be triangulated? International Society of Nurses. Available: http://www.isncc.org/news/triangle.htm [Accessed: 15/09/2003].

HUISAMEN, P. 2005. Die effek van die besluitnemings- en lewensdoelkomponente van die SAPD se Selfbestuur Personeelkapasiteitsbouprogram (The effect of the decision-making and purpose-in-life components of the SAPS Self-Management personnel capacity-building programme). Potchefstroom: North-West University. (PhD Thesis)

HUISAMEN, P. \& WEYERS, M.L. 2005. Die SAPD se Selfbestuursprogram: die aard en effek van die besluitnemingskomponent op student-konstabels (The SAPS Self-Management Programme: the nature and effect of the decision-making component on student constables). In: HUISAMEN, P. Die effek van die besluitnemings- en lewensdoelkomponente van die SAPD se Selfbestuur Personeelkapasiteitsbouprogram (The effect of the decision-making and purpose-in-life components of the SAPS Self-Management personnel capacity-building programme). Potchefstroom: North-West University. (PhD Thesis)

JACKSON, S.L. 2003. Research methods and statistics: a critical thinking approach. Belmont (Calif.): Thomson/Wadsworth.

JOO, S. 1998. Personal financial wellness and worker job productivity. Virginia Polytechnic Institute and State University. (PhD Thesis)

KIM, J. \& GARMAN, E.T. 2004. Financial stress, pay satisfaction and workplace performance: financial education. Compensation \& Benefits Review, 36(1):69-76.

KRUGER, J.W. 2001. 'n Impakstudie van 'n lewensvaardigheidsprogram gerig op gemeenskap/persoonsverryking deur die uitbouing van selfkennis. Johannesburg: RAU. (MA Dissertation) 
LEE, D. 1997. Employee stress: the true cost. John Liner Review, 11(3):33-38.

MASEMOLA, M.J. 2003. The impact of financial problems on productivity of employees of the department of social services, population and development, Ermelo District. Pretoria: University of Pretoria. (MSD - EAP Mini Dissertation)

MEYER, M., OPPERMAN, C. \& DYRBYE, C. 2003. Measuring ROI in training. Randburg: Knowres Publishing.

NELSON-JONES, R. 1991. Lifeskills: a handbook. London: Dotesios.

ONI, S.A., OBI, C.L., OKONE, A., THABEDE, D. \& JORDAAN. A. 2002. The economic impact of HIV/AIDS on rural households in Limpopo Province. Available: https://www.up.ac.za/dspace/bitstream/2263/4740/1/Oni_Economic(2002).pdf [Accessed: 28/2/ 2009].

PATTON, M.Q. 2002. Qualitative research \& evaluation methods. London: Sage Publications.

ROOTH, E. 2000. An investigation of the enhanced relationship between participants in lifeskills courses and the environment. Pretoria: Human Sciences Research Council.

SAPS see SOUTH AFRICA (REP), SOUTH AFRICAN POLICE SERVICE.

SKINNER, L. 2007. Educators aim to turn out fiscally responsible adults. Investment News, September 10, 2007.

SOUTH AFRICA (REP), SOUTH AFRICAN POLICE SERVICE. 2004a. Training prospectus. Pretoria: SAPS. Available: http://www.is.org.za/training/prospectus/vision mission.htm [Accessed: 18/10/2005].

SOUTH AFRICA (REP), SOUTH AFRICAN POLICE SERVICE. 2004b. Be money wise. Pretoria: SAPS.

SOUTH AFRICA (REP), SOUTH AFRICAN POLICE SERVICE. 2005. Annual report: 2003-2004. Pretoria: Government Printer.

SOUTH AFRICA (REP). 2002. Financial Advisory and Intermediary Services Act (No. 37 of 2002). Pretoria: Government Printers.

STEYN, H.S. 2000. Practical significance of the difference in means. Journal of Industrial Psychology, 26(3):1-3.

WEYERS, M.L. \& HUISAMEN, P. 2005. The return on investment (ROI) of the SAPS SelfManagement Programme: with special reference to its decision-making and purpose-in-life components. In: HUISAMEN, P. Die effek van die besluitnemings- en lewensdoelkomponente van die SAPD se Selfbestuur Personeelkapasiteitsbouprogram (The effect of the decision-making and purpose-in-life components of the SAPS Self-Management personnel capacity-building programme). Potchefstroom: North-West University. (PhD Thesis)

WEYERS, M.L. \& RANKIN, P. 2007. The Facilitation Assessment Scale (FAS): Measuring the effect of the outcomes of workshops. Social Work Researcher-Practitioner/ Maatskaplikewerk-Navorser-Praktisyn, 19(1):92-112.

WEYERS, M.L., STRYDOM, H. \& HUISAMEN, A. 2008. Triangulation in social work research: theory and examples of its practical application. Social Work/Maatskaplike Werk, 44(2):207-222. 
WILLIS, L.E. 2008. Against financial-literacy education. Iowa Law Review (University of Iowa). Publication Date: 01/11/2008.

Dr Arnel Huisamen, Police Social Work Services, SAPS, Mossel Bay; Prof Mike Weyers, Social Work Division, School for Psychosocial Behavioural Sciences, North-West University, Potchefstroom, South Africa. 